\title{
China Belt and Road Initiative: Give-and-Take of Infrastructure Development in the North Africa Subregion
}

\author{
William G. Dzekashu \\ Multifamily Representative at the Office of Recapitalization \\ U.S. Department of Housing and Urban Development \\ 451 7th St SW, Washington, DC 20410, USA
}

Tel: 240-687-7155Ｅ-mail: wdzekashu@hotmail.com

Julius N. Anyu

Professor at the School of Business and Public Administration

University of the District Columbia

4200 Connecticut Ave NW, Washington, DC 20008, USA

Tel: 202-274-7175Ｅ-mail: jndumbe@udc.edu

Received: January 28, 2021

doi:10.5296/wjbm.v7i1.18258
Accepted: April 6, 2021

Published: June 23, 2021

URL: https://doi.org/10.5296/wjbm.v7i1.18258

\begin{abstract}
It is not a secret that Africa is richly endowed with raw materials, which has raised the stakes for foreign interests. The amplification of these riches has created a sense of urgency in developed nations to enter partnerships to have access to the resources. North Africa, though more advance than its sub-Saharan neighbors falls in the essential corridor of the Belt and Roads Initiative (BRI); and thus, requires infrastructure improvement to meet the overall BRI agenda. This yearning for infrastructure development in Africa has generally been met by China's search for natural resources. The BRI is that infrastructure investment platform that allows for connectivity between member nations. This semi-systematic literature review identifies and appraises relevant research and collects and analyzes data about the impact of BRI on development in this subregion. Even though the BRI has shown some evidence of constructive growth in infrastructure connectivity, the opaque nature of the engagements has been the subject of harsh criticism; with some critics describing China's motive as an attempt to recolonize Africa. Chinese partnerships in Africa have resulted in major investments and




\section{Macrothink}

World Journal of Business and Management

ISSN 2377-4622 2021, Vol. 7, No. 1

credit flows providing the much-needed resources to the BRI member countries to implement the very much needed development schemes, despite the main challenge that remains - sustenance of these extensive projects. The most significant implication of the BRI has been the concern about a possible conflict between China and the US. A key to averting open conflict between China and the US is through an alliance and coordinated response by Europe and the US.

Keywords: Africa, BRI, China, Debt, Development, Europe, FDI flow, FDI stock, GDP, Infrastructure, Loans, North Africa, Trade, United States 


\section{Introduction}

Africa is known for its abundance of rich natural resources that serve as raw materials for finished goods the world over. The continent is estimated to comprise over $90 \%$ of the world's platinum and cobalt supply, nearly $75 \%$ of the world's coltan, $67 \%$ of the world's manganese supply, half of the world's gold supply, 35\% of the world's uranium supply (Maverick, 2020) - and 9.6\% of the world global oil output. These estimates of abundance of resources have raised the stakes for foreign exploitation-turning Africa to an attractive battleground for global powers who have varying quid pro quo interests in the continent ranging from investment, military dominance, infrastructure development, diplomacy, soft power, trade, and geopolitics. Africa is also important strategically because of the 54 votes in the United Nations General Assembly (UNGA) that these global powers use for diplomatic scores. The amplification of these riches has created a sense of urgency in developed nations to seek partnerships for the exploitation of the resources in return for infrastructure financing. Most African markets are deemed to be emerging, placing Africa at the forefront of academic discourse about China's Belt and Road Initiative (BRI). The discussions focus on the impact of the BRI on economic and infrastructure development. Though future implications tend to paint a bleak outlook, at times turning contentious due to the skepticism about what China's motives are and the strategy employed in their engagements. In addition, about a third of China's investments in the continent are in the mining sector. On the flip side, there is less discussion about how the West views Africa. Even though the West has demonstrated interest in Africa, no country has demonstrated bigger interest in Africa than China. Brussels has negotiated free trade agreements with at least 40 African countries, but it is not clear whether this represents a balanced two-way trade. What is clear for the time being is that Africa has resources and China has access. The EU pledged to mobilize the sum of \$54 billion in Africa by 2020 for sustainable development, evidence that she wants access to the African market. In 2016, Israel sponsored different projects (solar, water, and agricultural technologies) in Senegal. In the same year, when Senegal co-sponsored a resolution condemning the illegal construction of Jewish Settlements in the West Bank, Israel retaliated by cancelling the Mashav Drip-Irrigation Project-a scheme that permitted an approximately 700 farming families in Senegal to triple their annual crop harvests. Therefore, why is the case of China different?

BRI engagements have often been criticized as debt-trap diplomacy, which according to the narrative, China provides funding to developing economies for infrastructure projects under rather opaque terms, while strategically leveraging the member country's obligation for economic, military, or political favors (Risberg, 2019). The three main reasons commonly advanced in explanation of China's growing investment in Africa include: (1) the craving for solid base of natural resources to sustain her fast-growing economy, (2) the requirement to expand her geopolitical influence globally, and (3) outrightly taking advantage of growth opportunities offered by the developing markets in Africa (Maverick, 2020). Some critics have gone as far as describing China's motive as an attempt to recolonize Africa. This strong language was echoed by the United States (US) Secretary of State-Hillary Clinton in the following words: "Africa should beware of the new colonialism played by China" (China 


\section{$\Lambda$ Macrothink}

World Journal of Business and Management

ISSN 2377-4622

2021, Vol. 7, No. 1

Times, 2011). The current US administration on its part in 2018 announced a plan to invest US\$60 billion in African economies, leading critics to express doubts about the renewed interest of the US in Africa especially after the reproachful comments by President Trump about the continent (Dzekashu \& Anyu, 2020). The US in the last decade has gradually disengaged from the Middle East, and in the same timeframe, Europe has battled internal challenges, yielding to China as the new actor who has slowly been exerting larger influence across the African continent. China is strategically ramping up engagement with countries such as Algeria, Egypt, and Morocco, all located at the intersection of the Mediterranean, and the Middle East. Dzekashu and Anyu (2020) underscore that much emphasis on the projected negative outcomes of the BRI engagements in Africa tend to shroud the benefits of economic and infrastructure development.

China refers to Africa as the world's largest region yet to be developed and it is against this backdrop that she developed a working understanding in her coordinated continent-wide strategy anchored by the Forum on China-Africa Cooperation (FOCAC) framework which was built on the following five principles of peaceful co-existence: (1) mutual respect for territorial boundaries and sovereignty, (2) mutual non-aggression, (3), mutual non-interference in each other's internal affairs, (4) equality and cooperation for mutual benefit, and (5) peaceful coexistence. Despite the controversy around China's engagements in Africa, China views herself as a development partner to Africa where she provides both the financing facility and infrastructure development expertise. An important question that must be considered is: What are the available investment and financing options for North Africa if not China?

\subsection{Problem Statement}

Most African nations lag the rest of the world in key infrastructure, specifically in energy, road and rail transportation, and water infrastructure (Lakmeeharan et al., 2020). There is much focus in literature on the infrastructure shortage in the sub-Saharan Africa region, but North Africa, though consisting of more advanced economies, also has infrastructure and funding needs. The infrastructure gap identified by the African Development Bank (AfDB) in 2018 was estimated at US\$112 billion annually (Risberg, 2019). Currently, less than half of this amount is being financed according to Dzekashu and Anyu (2020). Furthermore, "this investment gap...[presented] a unique opportunity for the US and the West to engage with their African...[partners] to offer an alternative to what has become questionable Chinese investment practices" (Dzekashu \& Anyu, 2020, p. 21). With rapid urbanization, the labor force has been expanding by 20 million people annually, indicating that Africa's infrastructure needs are only poised to expand (Lauridsen, 2017). This projected growth in population confirms the pressing need for private investments within the continent that could only be addressed with external financing.

BRI has shown evidence of constructive growth in infrastructure connectivity, such as electricity generation, energy pipelines, and railway construction (Jin, 2017) in Africa as a whole. The scale of projects is huge especially with the rebranding of infrastructure projects completed by China before 2013 in member nations (Zou, 2019). AS previously indicated, 


\section{$\Lambda$ Macrothink}

World Journal of Business and Management

ISSN 2377-4622

2021, Vol. 7, No. 1

China's approach to development partnership in Africa has been viewed with sheer mistrust (Dzekashu \& Anyu, 2020), due to the vagueness of the agreements, therefore conjuring the possibility of debt distress in many borrower countries (Hurley, Morris, \& Portelance, 2018); an issue that critics have not relented on highlighting.

\subsection{Objective and Scope}

The objective of this article is to advance an independent synthesis of prevailing literature involving China's business dealings in Africa through the BRI; providing statistics on projects in Africa by subregion with keenness to North Africa defined by the United Nations (UN) to include Algeria, Egypt, Libya, Morocco, Sudan, Tunisia, and Western Sahara. The paper further provides an assessment of select projects and examination of the economic prospects in handpicked member-nations that have benefitted substantially from BRI engagements within the identified subregion. According to Dzekashu and Anyu (2020), the perception of the West about China's commitments in Africa differs from the views of China and most African nations who have benefitted from these engagements and argue that China has stood in the infrastructure gap as an alternative to the West. The question that this paper seeks to address is whether commitments under BRI lead to constructive development outcomes in the North Africa Subregion.

\section{Literature Review}

The BRI was established to reinforce China's economic leadership through engagement in vast infrastructure development (Swaine, 2015). By comparing the inward FDI stocks as a percentage of GDP across the continent, it appears Africa is benefitting from the BRI (Dahman-Saïdi, 2013b). Some nations have succeeded in leveraging financing and technical implementation from China for major projects more than others.

\subsection{Belt and Road Initiative Footprint in Africa}

Between the years 2014 and 2018, North Africa had executed about 228 projects for a value of US\$336.4 billion. Southern Africa holds the largest number of total projects completed - 509, followed by West Africa-421; and the corresponding values of these projects show that the Central Africa subregion received the least number of projects-106 with a total value of US\$112.7 billion (see Figure 1).

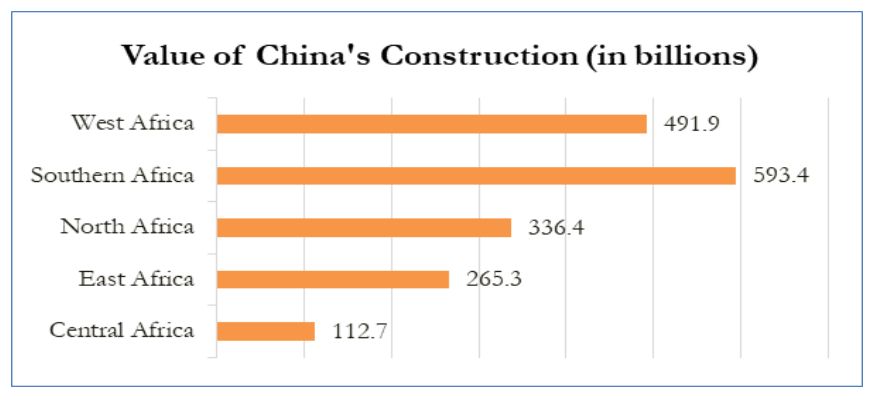

Figure 1. Value of China's construction by Subregion: 2014-2018

Source Data: Deloitte:

https://www2.deloitte.com/za/en/pages/energy-and-resources/articles/africa-construction-tren ds-report.html 


\section{1) Macrothink}

World Journal of Business and Management

ISSN 2377-4622

2021, Vol. 7, No. 1

A large proportion of Chinese FDI in Africa goes to the natural resource sector, but in recent years there is diversification to manufacturing, finance, and capital infrastructure (Dahman-Saïdi, 2013a).

Table 1. Chinese FDI Stock to North Africa: 2003-2018

\begin{tabular}{ccc}
\hline Country & FDI Stock (in US\$ billion) & Percentage \\
\hline Algeria & 18.34 & $42.5 \%$ \\
Egypt & 6.55 & $15.2 \%$ \\
Libya & 1.75 & $4.1 \%$ \\
Morocco & 1.64 & $3.8 \%$ \\
Sudan & 14.76 & $34.2 \%$ \\
Tunisia & 0.13 & $0.3 \%$ \\
Total & 43.18 & $100.0 \%$ \\
\hline
\end{tabular}

Source Data: JHU SAIS China-Africa Research Initiative, February 2019.

http://www. saiscari.org/s/FDIData_19Feb2020.xlsx

Consider the 2019 data in Table 1; the FDI stock between 2003 and 2018 for the North Africa subregion: $14.4 \%$, with about $42.5 \%$ going to Algeria and the least to Tunisia- 0.3 percent. According to Dahman-Saïdi (2013b), if FDI is anticipated to be a factor in achieving a nation's development goals, then African governments must implement an active strategy to attract FDI and make it work for the advancement of their countries by using valuable incentives. The UN Conference on Trade and Development (UNCTAD) in 2013 reported that $68 \%$ of total FDI equity income in Africa in 2011 was repatriated compared to $58 \%$ for all countries and 44\% for all the developing economies (Dahman-Saïdi, 2013b).

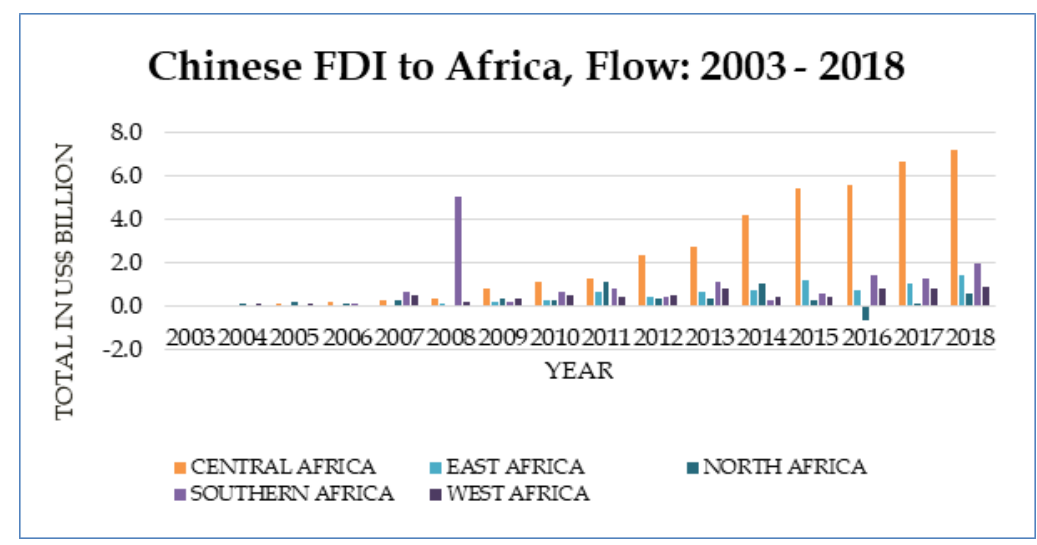

Figure 2. Chinese FDI Flow to Africa: 2003-2018

Note. The negative FDI flow shown in Figure 2 indicates that at least one of the components of FDI is not offset by positive amounts of the remaining components in 2016. These are instances of reverse investment or disinvestment.

Source Data: JHU SAIS China-Africa Research Initiative, February 2019.

http://www. saiscari.org/s/FDIData_19Feb2020.xlsx 
The observations of the FDI during the same period indicate an upward trend in China's engagements in the entire continent confirming China as a development partner who will be on the continent for a long time. Chinese partnerships in Africa have resulted in major investments and credit flow providing the much-needed resources to the BRI member countries for the implementation of needed infrastructure projects; even though one of the main challenges remains - ensuring the maintenance of these large-scale infrastructure projects. These nations have attracted external funding for the implementation of these projects. Below is a brief description of some key BRI projects undertaken in the North Africa subregions. These projects according to Metwally (2019) are consistent with the African Union's (AU) Agenda 2063 that seeks to connect all 54 African nations through transportation infrastructure - airports, high-speed railways, and modern highways. Most of East Africa is currently connected by both ports and railroad networks. Countries at the top of the list of largest borrowers within the North Africa Subregion include Egypt, Morocco, and Sudan. Some of the projects that these loans have financed include the El Gaili Cycle Power Plant, Khartoum Railway and Port, King Mohammed VI Bridge, Mohammed VI Tangier Tech City, New Administrative Capital, and Qarrel Thermal Station amongst others.

\subsection{Highlight of Select BRI Investment Projects in North Africa}

\subsubsection{Egypt: New Administrative Capital in East Cairo}

Egypt's New Administrative Capital is groundbreaking for the BRI. The traditionally long-standing relations between China and Egypt provides rationale for the latter being amongst the first nations to sign a memorandum of understanding (MOU) with the former. The Arab Spring protests of 2011 led to instability in the nations of North Africa leading to economic distress. China was one of few countries willing to extend credit assistance to Egypt in times of crisis. China launched several ventures including the creation of an industrial zone in the Gulf of the Suez, introduction of an electric train system for its new capital, and other investments in Western Sahara. Between 2015 and 2017, China lent Egypt the amount of US\$1.03 billion to finance earmarked infrastructure projects; and in the same period brought in about 1,900 Chinese nationals as workers on the construction projects.

Egypt has benefited to the tune of over US\$7 billion in infrastructure projects implemented by Chinese companies. Noteworthy construction projects in the pipeline in Egypt planned by China are the second phase of the New Administrative Capital of Egypt's Central Business District worth US $\$ 3.5$ billion and a petrochemical plant budgeted to cost US\$6.1 billion. Besides, China has had her eyes on a water storage station worth US $\$ 2.7$ billion and a coal power plant. The Administrative Capital project is currently under construction east of Cairo, a project launched in 2015; and according to Lindsey (2017), the first phase was estimated to cost LE380 billion (US\$45 billion ); while the entire project is anticipated to be built over seven years. The new administrative and financial capital of Egypt hosts the main government departments and ministries, and foreign embassies in a total area of 700 square kilometers (270 square miles) carved out for the realization of the project, which according to Fouly (2019), the population is projected to be 6.5 million to seven million people.

Egypt is a vital part of China's One Belt One Road initiative, due to its location and the close 
diplomatic relationship both countries have enjoyed over the years. In 2018, a Chinese consortium including Shanghai Electric and Dongfang Electric won a tender to construct a 6,000-megawatt (MW) coal-fired electricity-generating plant in Hamrawein, on the Red Sea, with a bid of US $\$ 4.4$ billion. In February 2020, because of the COVID-19 pandemic, Egypt postponed indefinitely the China-funded construction of the power plant at Hamrawein. It is anticipated that as the COVID-19 wanes, the project implementation shall be revived.

\subsubsection{Morocco: King Mohammed VI Cable-Stayed Bridge in Rabat}

Focusing on the transportation, energy, and real estate sectors, Chinese investments, and contracts in Morocco between 2014 and 2019 totaled US\$1.26 billion. In 2016, China's Chint Group built a 172MW of photovoltaic solar power generation capacity with Saudi Arabia's ACWA Power. The development of Morocco's Noor Ouarzazate solar complex - the world's largest solar power facility-exemplifies a constructive commercial synergy among partners from China, Arab Gulf states, Europe, and Morocco. (Tanchum, 2020). The King Mohammed VI cable-stayed bridge which cost US\$32.5 million (Cohen, 2018), is a testament to the constructive potential of Sino-European-Moroccan cooperation. The construction work started in 2011 and was completed in 2016 and has a daily traffic of 20,000. The bridge, a 42 kilometers-long, 200 meters high, and 30 meters wide project, was financed by the European Investment Bank (EIB) and the National Company of Motorways in Morocco and constructed by the China Railway Major Bridge Engineering Group.

Casablanca - Morocco said a US $\$ 10$ billion project to build an industrial and technology hub, which would create 100,000 jobs near the northern city of Tangier, would be financed by China's Haite Group, BMCE's Bank of Africa and the Moroccan government. Morocco and the Chinese government signed a MOU last year for the 2,000-hectare city. Mohammed VI Tangier Tech City will contribute to the development of economic activities in Tangier and northern Morocco. It is the result of a government policy of diversification of economic partnerships with several countries.

\subsubsection{Sudan: Port Sudan to Khartoum Railway and the Merowe Dam}

To circumvent Western sanctions, Sudan turned to China as a major supplier of development finance and investment (Roessler, 2013) and the latter helped establish Sudan's oil industry and provided agricultural assistance for the cotton industry. Sudan received over US $\$ 5$ billion from China in official development financing commitments (Roessler, 2016), , granting China's Sinohydro Corporation a US\$300 million contract to construct 486 kilometers of roads within the country, a project expected to make a significant contribution to improving Sudan's road transport network in the northern and central parts of the country. Earlier infrastructure projects were all related to the power sector, beginning with the construction of the El Gaili Cycle Power Plant in 2001, and the Qarrel Thermal Station in 2002. China later financed three substantial thermal generation projects for coal-fired and gas-fired stations in Port Sudan, Al-Fulah, and Rabak. Hence, a total of more than 2,200MW of new thermal generating capacity were added with Chinese support.

The $782 \mathrm{~km}$ Port Sudan to Khartoum railway line was launched in 2014 with China investing 
US $\$ 1.1$ billion of the total cost of US $\$ 1.5$ billion (Davis, 2016). This railway link was constructed with more than US $\$ 1.0$ billion in export credits from the Chinese government, a line that is part of Beijing's ambitious long-term plans for an intercontinental trade route connecting the east and west coasts of Africa by a series of road and railway links. This rail line according to Barber (2020) is planned to be extended to other countries in the sub-Sahara region through N'Djamena, Chad in the Central Africa sub-region, and the network of rail lines in East Africa.

Another high-profile power sector project - the Merowe Dam that generates 1,250MW was built for an estimated cost of US\$1.2 billion, a hydropower project only second to the Mambilla Hydropower project in Nigeria - the largest international project that China had ever participated in. Financiers of the project included the China EXIM Bank (US $\$ 400$ million), the Saudi Fund (US\$150 million), the Arab Bank for Economic Development in Africa (US\$100 million), the Kuwait Fund for Arab Economic Development (US\$100 million), and the Abu Dhabi Fund (US\$100 million). Chinese company Sinohydro was involved in the construction of the plant, while Harbin Power Engineering Company and Jilin Province Transmission and Substation Project Company took over the construction of the 1,776 kilometers of transmission lines for the project. Completion of the dam led to a major increase in the country's electrification rate and resulted in the resettlement of 55,000 to 70,000 residents away from the fertile agricultural areas surrounding the River Nile.

\section{Research Methodology}

This article employs a semi-systematic literature review method in which the results of both qualitative and quantitative articles specific to the BRI projects have been tracked overtime, analyzed, and evaluated. The objective was to identify any interpretable trends and patterns revealed (Snyder, 2019). The semi-systematic approach was utilized because the research aimed at answering a question that is broad in nature: do commitments under the BRI lead to constructive development outcomes in the North Africa Subregion. Another strategy implemented with the semi-systematic literature review method was to identify broad themes in literature, while analyzing the state of knowledge and review of contributions made through theoretical models. The lack of clarity in reporting of credit activities within project pipelines continues to be a source of risk of reporting inaccuracies. For the outcome of any research to be trustworthy, there are steps and actions required to be followed and taken, to ensure accurate and precise reporting. This lack of publicly reported sources of information about the BRI pipeline projects has resulted in development of creative methods for assessing the economic impact of partner commitments.

Hurley et al. developed an approach where they collated official publicly reported sources to build project lending pipelines for nations identified as highly vulnerable to debt distress (2018). Zhai (2017) on the other hand investigated the macroeconomic impact of BRI by implementing the global computable general equilibrium (CGE) model, which utilizes actual economic data to project economic reactions to changes in policy, technology, or other external factors. This approach permits provision of explicit links between changing production, consumption patterns, and changes in trade. Once obtained from the different 
methods, the data is then triangulated with information obtained from media and other sources. The gravity model - extracted from Isaac Newton's Law of Universal Gravitation is used widely to analyze trade impacts and patterns (Lu et al., 2018). The model theorizes that in international trade, countries trade in proportion to their market size (GDP), and the distance (proximity) between countries, represent the cost of trade. The model does not represent the indirect linkages between the various elements in the economies for different sectors at a more disaggregated level (Lu et al., 2018). Unlike the CGE model, the gravity model can only identify the static effects of transport infrastructure on bilateral trade, keeping all other factors constant. According to $\mathrm{Lu}$ et al. (2018), there is a positive relationship between transport infrastructure and connectivity and bilateral trade with a statistically significant impact in the study which analyzed the BRI region, the EU, and other nations. The use of both models is an effort to utilize a quantitative approach to determine the debt impact of BRI on member countries, though they are not without limitations.

\section{Research Findings and Results}

In Africa, BRI has been deemed to be complicated and contentious because it is difficult to separate the positive from the negative economic outcomes (Dzekashu and Anyu, 2020). The macroeconomic questions as to how constructive the BRI has been complex, hence the appreciation tends to focus on the suspicions by leading economic players who may not understand China's intentions. Below is an appreciation of the BRI on local economies which can be measured through debt sustainability and lending practices, approaches to labor practices (capacity building), and ethical issues (human rights and environmental awareness).

\subsection{Debt Sustainability and Lending Practices}

Some public reporting has expressed alarm about the implications of BRI for debt sustainability. It is anticipated that the sustainability of BRI financing will hinge in part on the yield of the BRI ventures (Hurley et al., 2018). There is also concern that debt problems will create an unfavorable degree of dependency on China as a creditor. The sustainability of a country's debt depends not only on macroeconomic variables but also on the structure of its debt portfolio. To further reduce risky loans and to ensure sustainable returns on investments, the international community must work with China (Gerstel, 2018). Unlike the US Marshall Plan which mainly dispersed aid in the form of grants that did not require repayment, China uses loans that often come at commercial interest rates. Between the years 2000 and 2017, Sudan appears to have borrowed more from China than any other country in the North Africa Subregion, while in the same period there was no loan to either Libya or Western Sahara (see Figure 3). 


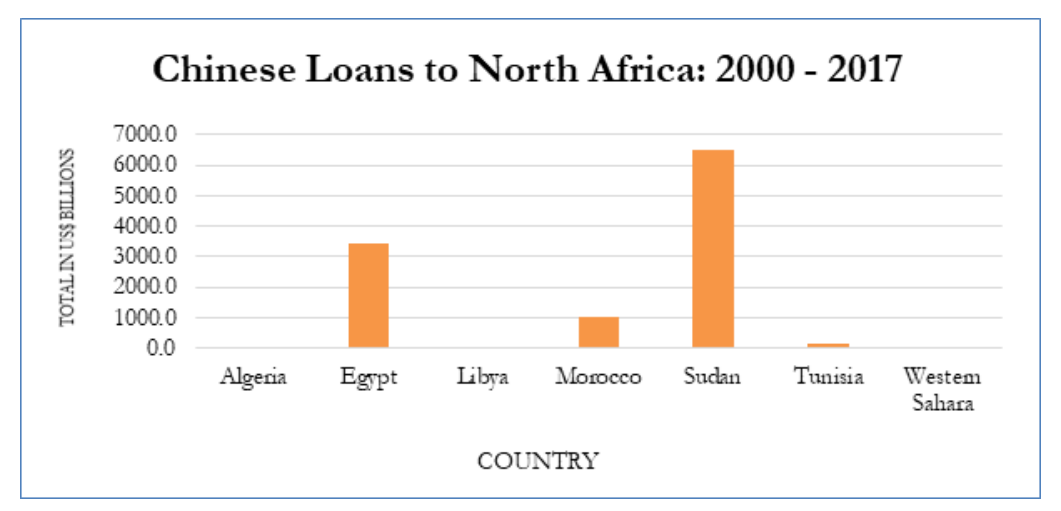

Figure 3. Chinese Loans to North Africa: 2000-2017

Source Data: JHU SAIS China-Africa Research Initiative, February 2019

http://www.sais-cari.org/s/LoanData_17July2020.xlsx

Although the BRI provides critical infrastructure funding to developing nations, it also leaves many with unsustainable debt. The IMF and other stakeholders have encouraged China to cooperate to help countries along the Belt and Road facing financial imbalances and high debt to be able to manage their debt load. According to Shepherd (2019), some BRI critics have complained about debt overload or "debt trap," in which one country lends too much money to another with limited ability to repay. The situation of Zambia-where China has taken over the national electricity company and the national broadcasting corporation due to the inability to meet loan repayment obligations has according to Soto and Hill (2020) served as an eye-opener and led many African states to reconsider engagements with China. It is yet to be seen whether the African nations can act upon the worries by re-writing the terms of engagement or completely abandoning the current understanding under the BRI. One thing that is evident is that the legality of some of the loans are being challenged in several nations - Kenya, Nigeria, Tanzania, Zambia — and China is under increasing ethical pressure from African governments and societies to come up with answers to the problem (Soto \& Hill, 2020).

\subsection{Labor Practices and Ethics}

The BRI has faced steep criticism over the practice of bringing Chinese nationals as workers to design and complete foreign construction projects rather than hiring local workers (Shepherd, 2019). China seems to be taking the criticism into account since the number of Chinese workers in the member countries since 2015 (see Figure 4) has been in decline. The overall question as to whether the BRI is a win for member nations is mainly to the opportunity cost of the projects. In Egypt for example, some opinions are against the concept of constructing a new Administrative Capital because the massive cost led to Egyptian citizens suffering from austerity measures, although others see it as a necessary solution for developing the country's infrastructure and attracting investors (Hussein \& Pollock, 2019). 


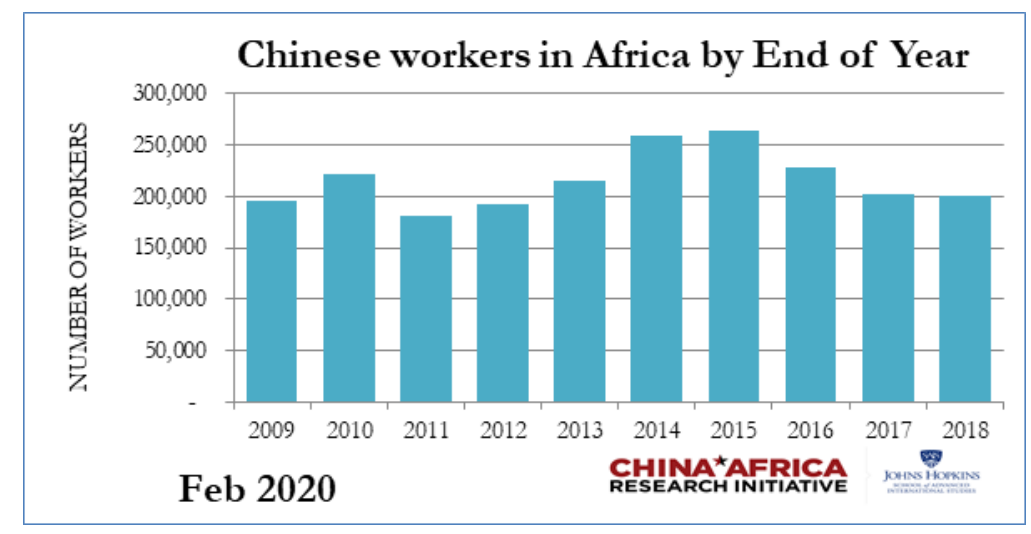

Figure 4. Chinese Workers in Africa: 2009-2018

Source Data: JHU SAIS China-Africa Research Initiative, February 2019

http://www.sais-cari.org/s/ LaborData_19Feb2020.xlsx

\subsection{Race for Economic Dominance}

Europeans appear to take a constructive approach to China, especially because many member states sought Chinese investment and imports after the 2008 global financial crisis which lasted longer in Europe than the US. After years of viewing China as a developing country and a systemic rival, Europe has since changed its stance and considers China an emerging global power, an economic competitor, and a strategic partner. Under the Obama administration, while the US contended with the implications of China transitioning from a developing economy (treated as such since its entry into the WTO in 2001) to the world's second-largest economy, the US economic competition against China has since intensified. Technological superiority is a key dimension in the race for global economic dominance between the US and China, even though the competition between both powers goes far beyond economic (Klein, 2020).

\section{Conclusions}

The BRI in member nations seems to generally have economic benefits-evident in the increase in annual GDP due to inward FDI stocks (Dahman-Saïdi, 2013b) across the continent. China, according to Ghafar and Jacob (2019) "uses trade, investment, and finance as noncoercive tools in its relations with North African countries," which may be same for the rest of Africa. This approach has encouraged competition amongst partners, such as the EU and Russia. The geographic position of North Africa makes it attractive because of its proximity to Asian, European, sub-Saharan African markets, and multiple industrial zones, and prime investments in infrastructure development (Ghafar \& Jacob, 2019). Today, China is Africa's largest trading partner where her trade has increased 40-fold in the last two decades in a market where she can dump her goods, and according to a McKenzie study, some 10,000 Chinese-owned firms operate in Africa. Beijing is selling its culture as in the case of Guinea Bissau where exit signs are written in Mandarin, while many nations in the continent are beginning to use Chinese currency for local trade. The population of Africa is projected to 
more than double by 2050 to about 2.2 billion people with over 60 percent under the age of 25 . Their race is to capture both the present market as well as the future.

Obstacles to security and diplomatic cooperation between China and North Africa are linked to China's economic priorities. Although China has made considerable in-roads into North Africa with the BRI, her political connections to the region are nonetheless shallow predominantly due to political instabilities in Algeria, Libya, and Tunisia. Morocco is the more open and ready BRI participant in the region. Scandals about corruption have hurt the standing of Chinese companies in Algeria where there is a general lack of transparency around construction engagements (Ghafar \& Jacob, 2019).

The most significant implication of the BRI has been the concern about a possible conflict between China and the US. The race for economic dominance has led to open questions about China's quest for even political and military dominance. Europe on her part does not view China's rise to a major economic power as a crucial issue, though they acknowledge that the latter is a dictatorial system (Ortega, 2020b). Over a period of 20 years of Sino-American relations, the US has expressed disappointment that the interactions between both powers have not led to more economic and political freedoms. The economic and security approach of the US towards China has been rather confrontational such as engaging in a trade war with Beijing. The three areas of competition between China and the US are 5G technology, artificial intelligence and semiconductors, and web-based services (Ortega, 2020a). If the US and Europe do not bridge the digital technology divide, Beijing will likely win the race to govern the digital technology space. This can only be accomplished through an alliance and coordinated response by Europe and the US even if not everything, but on technology dimensions. What is evident is that the US sees Africa as the new front to take on China where Washington is fighting it out for power and influence. The potential for conflict is not only with the US but to a lesser extent with other nations such as India over the Chinese proposed construction of a temporary naval base in Pakistan for example.

It is anticipated that the BRI is bound to continue to grow in the North Africa region if the countries remain stable, especially in Algeria, Egypt, and Morocco were the diplomatic and economic engagements are wanting (Ghafar \& Jacobs, 2019). North Africa is encouraged to negotiate its funding with China transparently, owing to the poor patterns in Chinese projects in Latin America and South Asia (Ghafar \& Jacobs, 2019). To accomplish constructive results in the relations with China, the subregion should consider a multilateral rather than a bilateral approach. This approach could ensure regional coordination on trade, investment, diplomacy, and defense cooperation with any of the front players including Russia, the European Union (EU), and the US. The US and European policymakers must understand that the gaps left by their retreat from North Africa will be filled by rising powers like China, seeking to further develop patron-client relations with states in the region. Europe should be wary of the security risks posed by an increased Chinese presence in the region and should work quicker to implement proposed trade agreements (Ghafar \& Jacob, 2019). Beijing has resisted pressure for changes from Washington and Brussels to reduce government-controlled state-owned enterprises (SOEs) and subsidies (Ortega, 2020b). The US and Europe agree on the shared value to uphold respect for human rights - an area they believe they could put 
pressure on China (Ortega, 2020b).

China's approach under the BRI has been described as hostile, and her overall economic practices, military expansion, and coercive political and ideological tactics in all of Africa are not to be ignored (Risberg, 2019). With the current COVID-19 pandemic and the looming global economic downturn, China will need to recalibrate its aspirations under the BRI; meaning she is likely to be selective and will limit outbound investments in the short-term. Adjustments to her expectations and targets will not include abandonment of the Maritime Silk Road because her partners have too much financial and political capital stake (Calabrese, 2020). The Chinese attitude to her economic model is that the short-term problem of debt is outweighed by the long-term prospect of growth (Harding, 2020), and thus sees the criticism of the West as biased, even though it is responding positively to some of the criticisms in the areas of labor practices, ethics and human rights, and political engagement. If the BRI continues to be considered an investment facility, the ultimate responsibility for ensuring nations are not engulfed in debt-trap diplomacy on the sovereign nations and regions because according to Harding (2020), "much of the success of the BRI will depend on countries other than China."

\section{Abbreviations}

BRI: Belt and Road Initiative, COVID-19: Coronavirus, 2019, EU: European Union, FDI: Foreign Direct Investment, FOCAC: Forum on China Africa Cooperation, ICT: Information and Communication Technology, US: United States.

\section{References}

Anyu, J. N., \& Dzekashu, W. G. (2019). China's enterprise in Africa: Market entry strategies, implications for capacity building, and corporate social responsibility. Journal of Economics and Political Economy, 6(2), 172-180. http://dx.doi.org/ 10.1453/jepe.v6i2.1898

Barber, L. (2020). China's response to Sudan's political transition. Special Report. Retrieved on December 4, 2020 from https://www.usip.org/sites/default/files/ 2020-05/20200508-sr_466-chinas_response_to_sudans_political_transition-sr.pdf

Calabrese, J. (2020). China's Maritime Silk Road and the Middle East: Tacking against the wind. Middle East Institute. Retrieved on November 29, 2020 from https://www.mei.edu/ publications/chinas-maritime-silk-road-and-middle-east-tackingagainst- wind

China Times. (2011). Clinton warns against "new colonialism" in Africa. Reuters. Retrieved $\begin{array}{llll}\text { on } & \text { November } & 22 & \text { from }\end{array}$ https://www.reuters.com/article/us-clinton-africa/clinton-warns-against-new-colonialism-in-a frica-idUSTRE75A0RI20110611

Dahman-Saïdi, M. (2013a). Is the union of the Chinese dragon with the African lion nothing but a chimera? Part 1: Chinese Investment in Africa: What Characteristics? BSI Economics. http://www.bsi-economics.org/images/articles/a4.pdf

Dahman-Saïdi, M. (2013b). Is the union of the Chinese dragon with the African lion nothing 
but a chimera? Part 2: What Opportunities for African Development? BSI Economics. http://www.bsi-economics.org/images/articles/a5.pdf

Davis, A. (2016). China is building and funding Africa's rail transport infrastructure. Highways Today. Retrieved on November 29, 2020 from https:// highways.today/2016/12/18/china-building-funding-africas-rail-transport-infrastructure/

Dzekashu, W. G., \& Anyu, J. N. (2020). China's Belt and Road Initiative: Will it make or mar development in the Central and West Africa Subregions? Journal of Public Administration and Governance, 10(4), 19-36. https://doi.org/10.5296/jpag.v10i4.17876

Fouly, M. (2019). Feature: Chinese construction projects in Egypt's new capital city model for BRI-based cooperation. Xinhua. Retrieved on November 29, 2020 from http://www.xinhuanet.com/english/2019-03/18/c_137902708.htm

Gerstel, D. (2018). It's a (debt) trap! Managing China-IMF cooperation across the Belt and Road. Center for Strategic \& International Studies. Retrieved on November 30, 2020 from https://csis-website-prod.s3.amazonaws.com/s3fs-public/181017_DebtTrap.pdf?MKq761YIB piOgy PZ9EyK2VUD7on_2rIV

Ghafar, A. A. \& Jacobs, A. (2019). Beijing calling: Assessing China's growing footprint in North Africa. Brookings. Retrieved on November 24, 2020 from https://www.brookings.edu/wp-content/uploads/2019/09/Beijing-Calling-Assessing-China\%E 2\%80\%99s-Growing-Footprint-in-North-Africa_English-1.pdf

Harding, R. (2020). China's Belt and Road initiative and its impact on the Middle east and North Africa. International Banker. Retrieved on November 29, 2020 from https://internationalbanker.com/finance/chinas-belt-and-road-initiative-and-its-impact-on-themiddle-east-and-north-africa/

Hurley, J., Morris, S., \& Portelance, G. (2018). Examining the debt implications of the Belt and Road Initiative from a policy perspective. Journal of Infrastructure, 3(1). https://doi.org/10.24294/jipd.v3i1.1123

Hussein, A. A. A. \& Pollock, E. (2019). Sustainable development approaches in Egypt. IOP Conference Series: Earth Environmental Science, 297012027. https://doi.org/10.1088/1755-1315/297/1/012027

Jin, F. (2017). The belt and road initiative: Progress, problems, and prospects. Center for Strategic \& International Studies. Retrieved June 3, 2020 from https://www.csis.org/belt-and-road-initiative-progress-problems-and-prospects

Johns Hopkins University SAIS China Africa Research Initiative. (2020a). Data: Chinese investment in Africa. China Africa Research Initiative, School of Advanced International Studies, Johns Hopkins University. Retrieved November 12, 2020 from http://www.sais-cari.org/s/LoanData_17July2020.xlsx

Johns Hopkins University SAIS China Africa Research Initiative. (2020b). Data: Chinese investment in Africa. China Africa Research Initiative, School of Advanced International 
Studies, Johns Hopkins University. Retrieved June 10, 2020 from http://www.sais-cari.org/s/FDIData_19Feb2020.xlsx

Johns Hopkins University SAIS China Africa Research Initiative. (2020c). Data: Chinese investment in Africa. China Africa Research Initiative, School of Advanced International Studies, Johns Hopkins University. Retrieved November 12, 2020 from http://www.sais-cari.org/s/LaborData_19Feb2020.xlsx

Klein, A. O. (2020a). The U.S.-China race and the fate of transatlantic relations. Part I: Tech, values, and competition. Center for Strategic \& International Studies. Retrieved on November 25 , 2020

from

https://www.csis.org/analysis/us-china-race-and-fate-transatlantic-relations-0

Klein, A. O. (2020b). The U.S.-China race and the fate of transatlantic relations. Center for Strategic \& International Studies. Part II: Bridging differing geopolitical views. Retrieved on November 25 , 2020

from https://www.csis.org/analysis/us-china-race-and-fate-transatlantic-relations-0

Lakmeeharan, K., Manji, Q., Nyairo, R., \& Poeltner, H. (2020). Solving Africa's infrastructure paradox. McKinsey \& Company. Retrieved on November 22, 2020 from https://www.mckinsey.com/business-functions/operations/our-insights/solving-africas-infrastr ucture-paradox

Lauridsen, M. (2017). Africa needs more private investment. Here's how to make it happen. World Economic Forum. Retrieved on October 30, 2020 from https://www.weforum.org/agenda/2017/10/how-to-boost-investment-in-africa/

Lindsey, U. (2017). The anti-Cairo. Places. Retrieved on November 29, 2020 from https://placesjournal.org/article/the-anti-cairo/?gclid=Cj0KCQiAqo3-BRDoARIsAE5vnaIDB JtWIMuD03ZwhJ1sf1qpwL3aiSCZixZlYkT8dmgLviHeAtYLUZIaAhA9EALw_wcB\&cn-re loaded $=1$

Lu, H., Rohr, C., Hafner, M. \& Knack, A. (2018). China Belt and Road Initiative: Measuring the impact of improving transport connectivity on international trade in the region - a proof-of-concept study. Rand. https://doi.org/10.7249/RR2625

Maverick, J. B. (2020). The 3 reasons why Chinese invest in Africa. Investopedia. Retrieved on November 22, 2020 from https://www. investopedia.com/articles/active-trading/081315/3-reasons-why-chinese-invest-africa.asp

McKenzie, B. (2017). Belt \& Road: Opportunity \& risk: The prospect and perils of building China's New Silk Road [Web report]. Retrieved November 1, 2020 from https://www.bakermckenzie.com/-/media/files/insight/publications/2017/10/belt-road/baker_ mckenzie_belt_road_report_2017.pdf

Metwally, H. A. B. (2019). BRI: Six years of success in Africa. China.org.cn. Retrieved June 20, 2020 from http://www.china.org.cn/opinion/2019-04/25/content_74720 150. htm

Risberg, P. (2019). The give-and-take of BRI in Africa. Center for Strategic \& International 
$\begin{array}{llllll}\text { Studies. } & \text { Retrieved } & \text { July } & 27, & 2020 & \text { from }\end{array}$ https://csis-prod.s3.amazonaws.com/s3fs-public/NewPerspectives_APRIL2019_Risberg.pdf

Roessler, P. (2013). Chinese development finance and strategies of political (and territorial) survival in Sudan. Aid Data. Retrieved on November 29, 2020 from https://www.aiddata.org/blog/chinese-development-finance-and-strategies-of-political-and-ter ritorial-survival-in-sudan

Shepherd, L. (2019). China invests heavily in global infrastructure projects. SHRM. Retrieved $\begin{array}{llll}\text { on } & \text { November } & 30, & 2020\end{array}$ https://www.shrm.org/resourcesandtools/legal-and-compliance/employment-law/pages/global -china-belt-and-road-initiative.aspx

Snyder, H. (2019). Literature review as a research methodology: An overview and guidelines. Journal of Business Research, 104, 333-339. https://doi.org/10.1016/j.jbusres.2019.07.039

Soto, A. \& Hill, M. (2020). Africa starts to have second thoughts about that Chinese money. Bloomberg Business Week. Retrieved on December 21, 2020 from https://www. bloomberg.com/news/articles/2020-07-22/chinese-credit-fuels-debt-crisis-in-africa

Swaine, M.D. (2015). Chinese views and commentary on the "One Belt, One Road" Initiative. China Leadership Monitor, No. 47. Retrieved December 4, 2020 from https://www.hoover.org/research/chinese-views-and-commentary-one-belt-one-road

Tanchum, M. (2020). China's challenge in Morocco's Africa-to-Europe commercial corridor. East Asia Forum. Retrieved on November 24, 2020 from https://www.eastasiaforum.org/2020/08/01/chinas-challenge-in-moroccos-africa-to-europe-co mmercial-corridor/\#: :text=Focusing\%20on\%20the\%20transportation $\% 2 \mathrm{C} \% 20$ energy,Sale $\%$ 2C \%20the\%20longest $\% 20$ in $\% 20$ Africa.

Zhai, F. (2017). China's Belt and Road initiative: A preliminary quantitative assessment. Journal of Asian Economics, 55, 84-92. https://doi.org/10.1016/j.asieco.2017.12.006

Zou, M. (2019). Corporate social responsibility on the Belt and Road. Australian Institute of International Affairs. Retrieved on November 15, 2020 from https://www. internationalaffairs.org.au/australianoutlook/corporate-social-responsibility-belt-road/

\section{Glossary}

FDI: Foreign Direct Investment is an investment made by a firm or individual in one country into business interests located in another country. Generally, FDI takes place when an investor establishes foreign business operations or acquires foreign business assets in a foreign company.

FDI Stocks: Foreign Direct Investment stocks measure the total level of direct investment at a given point in time, usually at quarterly, semi-annually, or on annual basis. The outward FDI stock is the value of the resident investors' equity in and net loans to enterprises in foreign 


\section{Macrothink}

World Journal of Business and Management

ISSN 2377-4622

2021, Vol. 7, No. 1

economies. The inward FDI stock is the value of foreign investors' equity in and net loans to enterprises resident in the reporting economy. FDI stocks are measured in USD and as a share of GDP. FDI creates stable and long-lasting links between economies.

FDI Flows: Foreign Direct Investment flows record the value of cross-border transactions related to direct investment during a given period, usually a quarter or a year. Financial flows consist of equity transactions, reinvestment of earnings, and intercompany debt transactions.

GDP: Gross Domestic Products is the monetary value of all finished goods and services made within a country during a specific period. GDP provides an economic snapshot of a country and is used to estimate the size of an economy and growth rate. GDP can be calculated in three ways, using expenditures, production, or incomes.

\section{Copyright Disclaimer}

Copyright for this article is retained by the author(s), with first publication rights granted to the journal.

This is an open-access article distributed under the terms and conditions of the Creative Commons Attribution license (http://creativecommons.org/licenses/by/3.0/). 